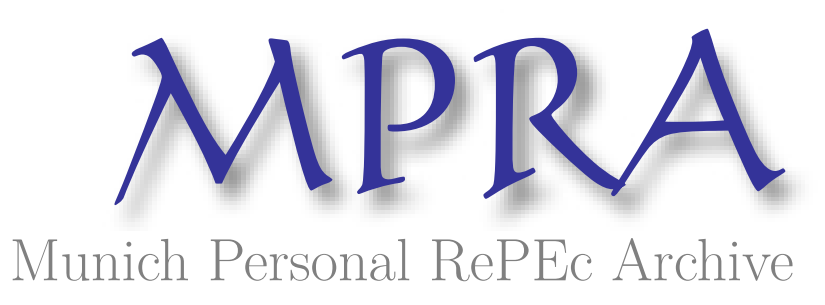

\title{
GOVERNMENT ROLE DURING THE GLOBAL FINANCIAL CRISIS
}

Suleymanov, Elchin and Alirzayev, Elvin

Qafqaz University, Qafqaz University

3 October 2013

Online at https://mpra.ub.uni-muenchen.de/51592/

MPRA Paper No. 51592, posted 13 Dec 2013 14:43 UTC 


\title{
GOVERNMENT ROLE DURING THE GLOBAL FINANCIAL CRISIS
}

\author{
ALIRZAYEV Elvin * \\ SULEYMANOV EIchin ${ }^{\dagger}$
}

\begin{abstract}
In this study we investigated government hand in the Global Financial Crisis. Before, during and after crisis government attempted to solve and avoid the turmoil. But did he succeed? Beginning with low interest rates set by FED, US government political pressures to enable more Americans to buy homes, unrestrained financial system despite of regulations and fines, human greedy were the main reasons for Great Recession.

More than 30 years of deregulation and reliance on self-regulation by financial institutions was the one big reason for crisis. Besides showing the stages crisis passed, the paper also examines penalties government gave to the financial intermediaries for breaking law in past related to crisis. Showing the emerging process of crisis, the article mainly restricted on US economy where was the epicenter of problem - and government, while the U.S. financial system stumbles, it may take the rest of the world down with it.

The actuality of the topic is that it was also a social crisis because, unemployment in US had reached to 50 millions which means they also lost their social insurances, and 16 million families had lost their homes. Several corporations bankrupted, in spite of more than these were saved by government. While financial crisis turned into social and economic turmoil it became government prior issue to solve.
\end{abstract}

Keywords: Global Financial Crisis, US economy, government failure, crisis recovery

JEL : H30, G01, G18, G28, H12, H81

\section{Introduction}

The recession officially began in December 2007. It peaked with the collapse of Lehman Brothers and the potential collapse of the insurance giant AIG in September 2008.

Before crisis, we can see a number of government social programs which abused by speculators and was one of the essential reasons of crisis. In the other side, lax regulation and incorrect orientation in monetary policy of US led to biggest crisis since Great Depression.

The crisis occurred by U.S. financial system has significantly depressed economic activity during the last years, laying a serious threat to the country's ability to quick return to a path of solid economic growth. One of the main reason for the crisis was the import of too much credit at too low a price as well as insufficient capital. As we know the US government role was huge in there pushing billion dollars into markets and allowing market to decide the future of global financial system.

\footnotetext{
*Department of Finance, Qafqaz University, Baku, AZERBAIJAN eelirzayev@qu.edu.az

${ }^{\dagger}$ Department of Finance, Qafqaz University, elsuleymanov@qu.edu.az
} 
Thus, the sudden shift to a much higher price for risk taking has led to a significant reduction in wealth and borrowing capacity; it has also forced a number of financial institutions to close and others to be merged with stronger operations. Those forces, in turn, are weighing heavily on consumption, the demand for housing, and businesses' investment.

Policymakers have responded to the financial turmoil with a set of unprecedented actions. Thus far, a systemic collapse of the financial system has not occurred, and conditions have improved noticeably in some financial markets.

The enormous monetary and fiscal policy actions of the past years represent a graduated response to the unfolding crisis. When the first signs of financial turmoil emerged, it was not clear either to policymakers or to most other observers just how serious the crisis would become. But who were not inside these greedy crowd might notice falling knife.

Businesses are care about only on their own future, mostly near future in this context. Government is the liable and responsible organization to set the puzzle in the economy and predict the future.

In the United States, businesses were given an incentive to expand and create new jobs, with tax cuts and deductions, transfer payments and other policies to strengthen household income, promote investment and increase aggregate demand.

Thus, sometimes problems may occur in private sector due to private sector mechanism. Only with government interfere it might be fixed. This calls in literature 'market failure'. But sometimes it may occur because of government behavior. In this 'government failure' case, problems might be solved changing government managing system.

This study approaches to the problem mostly from 'government failure` dimension and seeks government role on the eve of crisis.

\section{Government hand before crisis.}

After 1980`s, more "hot investment capital" began to flow into global markets-especially to the United States. At the same time, China, Japan and some OPEC countries invested into U.S. Treasury and other securities. While this led interest rates low, it also made mortgage interest rates at lower and attractive levels. The mortgage originators main purpose was to write mortgages using funds provided by financial institutions without watching risks carefully. They were paid for each originated mortgage but had no responsibility for loans gone bad. This was supported with political acts to make easier more Americans to buy homes (houses), in terms of the enlarging lending standards and the rise of subprime mortgages.

The Glass-Steagall Act of 1933 established the Federal Deposit Insurance Corporation (FDIC hereafter). The FDIC insured bank deposits up to $\$ 2500$; that limit climbed to $\$ 100.000$ by 1980 , and was raised to $\$ 250.000$ during the crisis in 2008. Depositors no longer needed to worry about their money`s future. And if banks were constraint of cash, they could borrow from the Fed easily. Which means, Fed would support banks not to fail from a lack of liquidity (FCIC, 2011).

The Glass Steagall Act, among other changes, separated investment banks from commercial banks, and New Deal reforms protected market share for the highly regulated part of the financial sector.

In 1977, Merrill Lynch issued something even more like a bank account: "cash management accounts" which allowed customers to write checks. Other money mutual funds followed (FCIC, 2010). Consumers liked the higher interest rates even they were not protected by FDIC deposit 
insurance. Assets of mutual funds jumped from $\$ 3$ billion in 1977 to more than $\$ 740$ billion in 1995 and $\$ 1.8$ trillion by 2000 (Wilmarth, 2002).

In 1960s, the commercial paper market jumped more than sevenfold and in 1970s it grew almost fourfold again. By 2000, commercial paper had risen to $\$ 1.6$ trillion, 10 times more than 1980 level. It seemed a win-win-win deal: the mutual funds could get a solid return, companies could borrow more cheaply and Wall Street firms could earn fees for putting the deals together (FCIC, 2011).

"Reforms" occurred by neocons included privatization of Social Security, tightening bankruptcy law, transferring health care burdens to patients, replacing income and wealth taxes with consumption taxes, substituting "personal reemployment and training accounts" for unemployment benefits, large unemployment reliefs, "No Child Left Behind" and school vouchers legislation, transferring private pensions to defined contribution plans, the movement against government "takings," and attempts to hand national resources over to private exploiters. In addition, "freeing" financial markets and money managers played a critical role in increasing homeownership - "success" of the ownership society policy envisioned by the neocons (Wray, 2005).

30-year mortgage introduced by New Deal government guarantees-making home ownership possible for low-income class for the first time - turned into a speculation-fueling, debt-pushing casino that bared home owners lots of liabilities. The program suggested the more ownership, the more vitality, which meant the more people will have a vital stake in the future of the country.

Before 1968, Fannie Mae mostly held the mortgages it purchased, profiting of funds and the interest paid on these mortgages. The 1968 and 1970 laws gave Government Sponsored Enterprises (GSEs) another option: securitization. A lender would set a pool of mortgages and issue securities backed by the mortgage pool. These securities would be sold to investors, with Ginnie (who was first) guaranteeing timely payment of principal and interest. In 1971, Freddie began to buy mortgages, pool them, and sell mortgage-backed securities and also charged for guarantee as well as Ginnie.

In 1980s and 1990s, the conventional mortgage market expanded, the GSEs grew significantly, and the market share of the FHA (The Federal Housing Administration) and VA (the U.S. Department of Veterans Affairs) declined. Fannie and Freddie had missions to support the mortgage market and maximize returns for shareholders. They did not originate mortgages; they purchased them - from banks, thrifts, and mortgage companies - and either held them in their portfolios or securitized and guaranteed them. Congress granted both enterprises special privileges thru exemptions from state and local taxes and a $\$ 2.25$ billion credit line each from the Treasury. The Federal Reserve provided services such as electronically clearing payments for GSE debt and securities as Treasury bonds. Which allowed Fannie and Freddie to borrow at least rates as the Treasury paid. Federal laws allowed for investment in GSE securities with relatively favorable capital requirements and no limits (FCIC, 2011).

The government sponsored agencies Fannie Mae and Freddie Mac were enhanced to expand and buy mortgage backed securities, including 'risky' sub-prime mortgages. The Federal Housing Enterprise Regulatory Reform Act of 2005 legislation, to control these excesses, was not passed into law. These actions should be added to the list of government interventions that were part of the problem (Taylor, 2008).

Securitization of mortgages began in the early 1980s. In the new policy regime, no financial institution could stand with long term fixed rate mortgages. Therefore, regulators released banks and thrifts to pursue higher revenue, and of course riskier activities. 
Most of the mortgages originally securitized in standards put by Fannie Mae and Freddie Mac that were covered by semi-government insurance. Strong underwriting standards and the guarantee revealed that these mortgages were virtually risk-free, in other words, the securities based on mortgages were also safe.

However, managed money had an appetite for risk and its accompanying high return. Therefore, riskier assets, including Alt-A and subprime mortgages (riskier than prime loans) were also securitized. For several reasons, securities based on non-conforming loans are much more difficult to value: these instruments have less history to calculate default probabilities and peculiar loans packaged together make it harder to see the overall risk. One of the advantages is to diversify risks if default probabilities of mortgages underlying a security are uncorrelated. So how can one value a security? It can be obtaining default probabilities for each mortgage included in the package, then assess the correlation of these probabilities.

It resulted that futures prices surged after 2000 as money flowed into markets, from pension funds, sovereign wealth funds, hedge funds, and foreign banks. This fortified some factors that pushed up prices, including rapid growth in China and India as well as some supply constraints and inventory manipulation. Government policies, especially export restrictions and US biofuels incentives, had also act a part. These policy choices were supported by rising commodities prices. A perfect scene was created in a way almost every participant's interest lay in continued price gains. Similarities with the real estate boom are notable (Wray, 2009).

The Federal Housing Administration (FHA) has been part of U.S. Housing and Urban Development (HUD) since 1965. FHA mortgages are the most popular non-conventional mortgages offering a $3.5 \%$ down payment minimum, low closing costs and easy credit qualifying for homebuyers who are not able to afford the $20 \%$ down payment of conventional loans.

In the 1992 Federal Housing Enterprises Financial Safety and Soundness Act, Congress extended HUD's privilege to set affordable housing goals for Fannie and Freddie. In 1995, President Bill Clinton announced an initiative to boost homeownership from $65.1 \%$ to $67.5 \%$ of families by 2000, and one component raised the affordable housing goals at the GSEs. Between 1993 and 1995, almost 2.8 million households entered the ranks of homeowners, nearly twice comparing the previous two years. There were opened new way home for the American middle class. This method continued by President George W. Bush, who, introduced a "Zero Down Payment Initiative" that under certain circumstances could remove the $\% 3$ down payment rule for first-time home buyers with FHA-insured mortgages (FCIC, 2011).

Government over time had charged several financial organizations for breaking law which federal and local governments prohibited to do in derivative markets. There were several examples.

In 1996 the Commodity Futures Trading Commission (CFTC hereafter) charged $\$ 150$ million in penalties and restitution the Japan's company Sumitomo (which lost \$2.6 billion in that operation) with using derivatives to manipulate copper prices and also to disguise the speculation and to finance the scheme. The CFTC also charged \$15 million Merrill Lynch with intentionally misdirect copper prices (CFTC, 1996).

In 2004 Fed set $\$ 70$ million penalty (plus $\$ 30$ million in restitution to borrowers) to CitiFinancial, for accusing the unit of selling credit insurance to borrowers without checking if they would qualify for a mortgage (O’Brien, 2004).

In 2002 Household Finance (later acquired by HSBC) was ordered to pay $\$ 484$ million in penalties and restitution to consumers. In 2004, Fannie and Freddie had violated accounting rules and faced corrections and fines. Struggling to remain dominant in securitization market, they 
loosened their underwriting standards, purchasing or guaranteeing riskier loans, and increasing securities purchases. The Office of Federal Housing Enterprise Oversight (OFHEO hereafter) focused more on accounting and other operational issues than on Fannie's and Freddie's increasing investments in risky mortgages and securities. In December 2003, Freddie agreed with OFHEO to pay a $\$ 125$ million penalty and correct governance, internal controls, accounting, and risk management. In 2006, OFHEO reported that Fannie had overstated earnings from 1998 through 2002 by $\$ 11$ billion and that it, too, had manipulated accounting in ways influenced by compensation plans. Fannie was fined \$400 million. In 2008 the OFHEO, the regulator of the GSEs reported significant rise in the incidence of fraud in mortgage lending in 2006 and the first half of 2007 (OFHEO, 2006).

In 2008 the Securities and Exchange Commission (SEC) announced a civil fraud lawsuit against Goldman Sachs. (Goldman agreed to pay for a "mistake" a fine of \$550 million, without admitting guilt) The SEC claims Goldman sold CDOs to investors without informing them that it allowed a hedge fund that was shorting the CDOs to select the underlying MBS (Wray, 2008).

According to Mortgage Market Statistical Annual Report 2009, subprime private label mortgage backed securities (PMBS) issued by Wall Street increased from $\$ 87$ billion in 2001 to $\$ 465$ billion in 2005; the value of Alt-A mortgage-backed securities increased from $\$ 11$ billion to $\$ 332$ billion.

In 2002, PMBS had reached $\$ 100$ billion. The issuances of PMBS that year totaled $\$ 134$ billion, of which $\$ 43$ billion in PMBS were issued by Wall Street financial institutions. In following years, as the market grew, Wall Street institutions fell below the major subprime issuers, so by 2005 only Lehman was among the top five issuers and Wall Street issuers as a group were only 27 percent of the $\$ 507$ billion in that year (MMSA, 2009).

In 2007, the notional value of CDS's had reached $\$ 62$ trillion, more than the combined GDP of the entire world which was $\$ 54$ trillion. By July 2008, it declined to $\$ 54.6$ trillion and by October 2008 to $\$ 46.95$ trillion. The system generated large profits for the companies until the default, and the number of bankruptcies began to soar. Soon newly generated outsized profits began to generate outsized losses, and in October 2008, losses became huge for companies (Nanto, 2009).

The number of suspicious activity reports related to mortgage fraud grew 20-fold between 1996 and 2005 and then more than doubled again to 2009 (FCIC, 2011).

When the Federal Reserve cut interest rates early in the new century and mortgage rates fell, home refinancing surged, climbing from $\$ 460$ billion in 2000 to $\$ 2.8$ trillion in 2003 (MMSA, 2009).

From 1978 to 2007 the amount of debt held by the financial sector soared from $\$ 3$ trillion to $\$ 36$ trillion, more than doubling as a share of GDP. The nature of many Wall Street firms changed taking greater and more diverse risks. By 2005, the 10 largest U.S. commercial banks held 55\% of the industry's assets (FCIC, 2011).

By 2005 and 2006 Wall Street was securitizing one-third more loans than Fannie and Freddie. In just two years, PMBS had grown more than \%30, reaching \$1.15 trillion in 2006, which $71 \%$ were subprime or Alt-A (MMSA, 2009).

From 2001 to 2007, mortgage debt almost doubled, and mortgage debt per household rose more than $63 \%$ from $\$ 91,500$ to $\$ 149,500$, even wages were the same. When the housing downturn hit, heavily indebted financial firms and families were beaten hardly (FCIC, 2011). 
The risk wasn't being taken on just by the big financial firms, but also by families. Nearly one in 10 mortgage borrowers in 2005 and 2006 took out "option ARM" loans, in which they might choose to make payments so low that their mortgage balances rose every month. The dangers of this debt were lifted up because transparency was not in question. During that year, $68 \%$ of "option ARM" loans originated by Countrywide Financial and Washington Mutual had low documentation requirements (FCIC 2011). Subprime ARM loans (adjustable rate mortgages) built to people with credit scores high enough to get mortgages with better terms. Additionally, lending standards began to decline due to laws also.

According to SCF-Chartbook, 2010 by FED, overall mortgage indebtedness climbed from $\$$ 5.3 trillion in 2001 to $\$ 10.5$ trillion in 2007 . The amount of mortgage debt per household rose from $\$ 91.500$ to $\$ 149.500$ between these years.

From 2000 to 2007 Moody's rated nearly 45.000 mortgage-related securities as triple-A. In 2006 alone, Moody's put its triple-A stamp of approval on 30 mortgage-related securities every working day (FCIC, 2011).

The U.S. government's housing policies were the major contributor to the financial crisis. These policies accelerated the development of a massive housing bubble between 1997 and 2007 and the creation of 27 million subprime and Alt-A loans, which most were ready to default as soon as the housing bubble began to deflate (FCIC 2011)

\section{Government role during the crisis.}

The recession officially began in December 2007. According to the most recent US government statistics, its effects on the job market were the worst in history as reflected in rise of underemployed workers, and millions of Americans were and still are suffering without work.

In the last years preceding the downturn, there were many signs that house prices were inflated, that too many homeowners were taking on mortgages and debt they could barely afford, and that risks to the financial system were growing unchecked. Many knowledgeable executives saw trouble ahead and tried to avoid, while countless Americans joined in the financial stream that seized the nation. Others were shouting to government officials, pointing to what would become a human disaster, not just an economic debacle (FCIC, 2011).

The economy shed 3.6 million jobs in 2008. The underemployment rate increased from 8.8\% in December 2007 to $13.7 \%$ in December 2008, reached 17\% in November 2010. The average length of time individuals spent unemployed spiked from 9.4 weeks in June 2008 to 18.2 weeks in June 2009, and 25.5 weeks in June 2010. 59\% of all job seekers, searched for work for at least 15 weeks. The labor market was daunting across the board, but it was especially bad among African American workers, whose jobless rate is $16 \%$, about $6 \%$ points above the national average; workers between the ages of 16 and 19 years old, at 24.6\%; and Hispanics, at $13.2 \%$. And the impact has been especially severe in certain professions: unemployment in construction, for instance, climbed to an average of $19.1 \%$ in 2009 , and averaged $20.6 \%$ during the first 11 months of 2010 (FCIC, 2011).

In the bailout process, the government rescued several financial institutions called "too big to fail”», while provided substantial financial assistance to nonfinancial corporations.

\footnotetext{
\$ The total of unemployed workers who are actively looking for jobs, those with part-time work who would prefer full-time jobs, and those who need jobs but say they are too discouraged to search

$\S$ so large and interconnected with other financial institutions or so important in financial markets that their failure would have caused cascading losses and failures in other institutions or markets
} 
When the housing bubble inflated and crisis launched, derivatives were in the first rank. The government concluded AIG was too big to fail and allocated more than $\$ 180$ billion to its rescue.

Without access to credit, and with uncertainty about the future of economy, corporations laid off workers or cut their investments, while others bankrupted.

In $2009,57 \%$ of U.S. companies were affected by credit constraints, leading to decisions to cut employment by $11 \%$, technology spending by $22 \%$, capital investment by $9 \%$, marketing by $33 \%$, and dividends by $14 \%$. And small businesses particularly felt the squeeze, which employ nearly $40 \%$ of the private-sector workforce. Unlike the large firms, which had come to rely on capital markets for borrowing, these companies had generally obtained their credit from traditional banks, other financial institutions, nonfinancial companies, or personal borrowing by owners. The financial crisis disrupted all these sources, making credit scarcer and more expensive (Campello et al., 2010).

Faced with financial difficulties, over 1.4 million households declared bankruptcy in 2009, up from roughly 1.1 million in 2008 (ABI, 2010). But even with the central bank's help, nearly $70 \%$ of banks tightened credit standards and lending by 2009 .

The Economic Stimulus Act of 2008 provided roughly $\$ 170$ billion in tax rebates for households and tax incentives for businesses. In October 2008, at the top of the crisis, the $\$ 700$ billion TARP was enacted; Aside from its emergency lending programs during the financial crisis, the Fed put about $\$ 1.7$ trillion into the economy from September 2008 to October 2010, mainly by buying financial assets such as mortgages-backed securities and Treasury bonds, a process described as "quantitative easing." And in November 2010, there were announced another $\$ 600$ billion in easing, designed to keep both long-term and short-term interest rates down (FCIC, 2011).

Fed's primary role at the investment banks during the crisis was not as a regulator but as a lender through the new emergency lending facilities (Bernanke, 2010). Mainly, Central Banks are not players in the markets, but regulators above them.

According to report of Congressional Budget Office, in October 2010, the Treasury Department reported that the TARP program would cost far less than the $\$ 700$ billion that Congress had appropriated in the fall of 2008, because banks had begun to repay the Treasury in 2009. In fact, Treasury announced, TARP would wind up costing about $\$ 29$ billion, mostly owing to the bailout of the automakers General Motors and Chrysler and the mortgage modification program. Overall, as spending increased during the recession, the federal deficit grew from $\$ 459$ billion in 2008 to $\$ 1.4$ trillion in 2009 (CBO, 2010).

Fannie Mae and Freddie Mac, the government-controlled companies had more than $71 \%$ of mortgage-backed bonds during 2007. Guarantees loans insured by the Federal Housing Administration, the government backed (either written or guaranteed) nearly 97 percent of U.S. mortgages in 2009. Since Fannie Mae and Freddie Mac were seized by the government in 2008 after losses on mortgage investments pushed them to the brink of collapse, taxpayers have injected almost $\$ 150$ billion to keep them solvent (Woellert, 2010).

Officials in US announced a \$25 billion settlement of foreclosure-abuse allegations with the five largest mortgage servicing firms: Bank of America Corp., Wells Fargo \& Co., J.P. Morgan Chase \& Co., Citigroup Inc. and Ally Financial Inc. As part of the state-federal settlement, the Fed announced $\$ 766.5$ million in fines against these banks.

Under the Fed's sanctions, Bank of America will pay $\$ 175.5$ million, Wells Fargo will pay \$87 million, JPMorgan Chase \$275 million, Citigroup \$22 million and Ally Financial pay \$207 
million. In the other hand, consumers are eligible for $\$ 1.5$ billion in cash payments who went through foreclosure between September 2008 and December 2011 (Zibel, 2012).

The bailout program and cost of government will be ended by next decade through Congressional Budget Office, FED, and FHFA (Federal Housing Finance Agency) with other officials.

\section{Policies and Impacts}

The vigorous monetary and financial policy actions of the past years responded to the crisis. When the first signs of financial turmoil emerged, it was not clear either to policymakers or to most participants just how serious the crisis would become. The Federal Reserve first began to supply additional liquidity to credit markets in August 2007 as pressures from losses on mortgage-related assets. In the following years, the central bank increased the funds it was providing by creating a number of new lending facilities to address emerging problems among financial institutions and in certain markets. It also expanded arrangements to banks charge each other for overnight loans of their monetary reserves, almost to zero by late 2009 .

Policymakers also took a series of significant measures to prevent the problems with solvency, which have improved conditions in some financial markets and thus far reduced the risk of a financial meltdown (CBO, 2009).

- Fed, in consultation with the Department of the Treasury, facilitated the sale of the investment bank Bear Stearns to the commercial bank JPMorgan Chase, in March 2008, by lending \$29 billion to a newly formed Maiden Lane LLC, against a \$30 billion portfolio of Bear Stearns's less liquid assets.

- FHFA -as a regulator- took Fannie Mae and Freddie Mac under protection, and the Treasury planned to issue up to $\$ 100$ billion of capital into each of the institutions by purchasing a share, or ownership.

- Fed extended a $\$ 60$ billion line of credit to the AIG. Additionally, the Federal Reserve Bank of New York arranged to lend up to $\$ 52.5$ billion to two newly formed LLCs to fund purchases of residential mortgage-backed securities and CDOs from AIG's securities portfolio.

- The Emergency Economic Stabilization Act of 2008 created the $\$ 700$ billion Troubled Asset Relief Program (TARP), which began purchasing preferred stock of commercial banks in late October. Most of the first half of that fund has been used to supply banks directly with capital. The law also temporarily raised the ceiling on deposit insurance from $\$ 100,000$ to $\$ 250,000$ per depositor.

- The Treasury, Fed, and FDIC jointly announced agreements with Citigroup and Bank of America to provide each with a package of asset guarantees, access to liquidity, and capital.

- The FDIC created the Temporary Liquidity Guarantee Program in October 2008 to bring confidence and enhance liquidity in the banking system. The program guarantees certain newly issued unsecured debt of banks, thrifts and provides full deposit insurance coverage for certain checking and non-interest-bearing deposit accounts, regardless of amount.

The global financial crisis was the consequence of the financialization process, or the creation of massive financial wealth and of the reactionary ideology based on self-regulated and efficient markets. In the other side, monetary policy after 2001-2 kept interest rates too low for too long - which increased credit supply to produce the high leverage levels associated with the crisis. Nourishing credit expansions with a major deregulation similarly occurred in the 1980s is a major historical fact explaining the crisis. The policy mistake that Greenspan recognized publicly in 2008 was not related to his monetary policy but to his support for deregulation (Bresser-Pereira, 2010). 
There are some explanations for the reasons for the crisis: lax regulation and oversight, rising inequality that encouraged households to borrow to cover spending, greed and irrational profusion, and excessive global liquidity - induced by US current account deficits that exported around the world with too many dollars (Wray, 2011).

It is also a social crisis because, according to the International Labor Organization, unemployment has grown from around 20 million to 50 million by the end of 2009 , whereas, according to the Food and Agriculture Organization, as the incomes of the poor were falling due to the crisis but the international prices of food commodities remained high, the number of undernourished people in the world increased by 11 percent in 2009, and, for the first time, exceeded 1 billion (Bresser-Pereira, 2010).

Some basic figures speak for themselves: global financial assets rose from $\$ 12$ trillion in 1980 to $\$ 196$ trillion in 2007. Global cross-border capital flows more than doubled between 2002 and 2007, with foreign investors holding one in four debt securities and one in five equities. While in 2000 only 11 countries had financial assets of more than $350 \%$ of gross domestic product (GDP), 25 countries had deepened their financial markets to the same extent by 2007 . As early as 1990, money managers had increased their control of US corporate equities from $8 \%$ in 1950 to $60 \%$. In the period from 1986 to 2006, the US financial sector as a whole increased its share of corporate profits from $10 \%$ to $30 \%$, while its outstanding debts grew from $20 \%$ of GDP in 1980 to $116 \%$ in 2007 (Blankenburg and Palma, 2009).

The United States allotted a total of $\$ 100$ billion to infrastructure: over $\$ 17$ billion in public transit and high-speed rail, $\$ 40$ billion for roads, bridges, dams, water, and $\$ 7$ billion to expand broadband access. Also government is planning to increase R\&D investments. Significant stimulus packages allocated for key science agencies such as the National Science Foundation ( $\$ 3$ billion), the Department of Energy's Office of Science ( $\$ 1.6$ billion), NASA ( $\$ 1$ billion), the Advanced Research Project Agency-Energy to support high-risk, high payoff research (\$400 million), the National Institutes of Health (\$10 billion) among others (FCIC, 2011).

These packages also plan to reduce the dependence on oil, doubling renewable energy production, fostering green technology research, and transforming the US energy transmission, distribution, and production system. Households with less income will receive aid and tax credits to better protect their homes from the weather. $\$ 30$ billion is on spent energy initiatives such as a new, smart power grid, advanced battery technology, and energy efficiency measures. The stimulus bill is allocating funds for "smart" technologies, a total of about $\$ 11$ billion (OECD, 2009).

The government's fiscal initiatives launched while the recession started. The Economic Stimulus Act of 2008, as a first stimulus package, involved temporary conforming loan limit increase for Fannie Mae, Freddie Mac and FHA. Most taxpayers below the income limit received a rebate of at least $\$ 300$ each (ESA, 2008).

Second stimulus package enacted since the beginning of the recession. According to The American Recovery and Reinvestment Act of 2009 (ARRA), to stimulate the weakening economy there were signed $\$ 787$ billion package which contained roughly $\$ 288$ billion in tax relief and $\$ 499$ billion in spending, which $\$ 224$ billion for education and health care, as well as extending unemployment benefits and $\$ 275$ billion for federal contracts, grants and loans (ARRA, 2009).

The stimulus packages included pledges on transparency and accountability, such as that all contracts and grant permissions will be posted publicly, that investments will be vetted and reviewed and whistleblowers protected. 
According to 'Inside Mortgage Finance Publications', 50\% of housing market is distressed property transactions. Also, in some states were natural disasters. These all results 16 million (family) foreclosures.

As people lost jobs, many also lost their health insurance. And their sickness grew up due to joblessness and they could not afford medicines. In other side, after foreclosure, they cannot maintain their life.

There were mainly two legislative actions: TARP - aimed at providing support for financial institutions and ARRA 2009 - aimed at providing stimulus to the economy.

On June 17, 2009, the Department of the Treasury presented financial regulatory reform. The proposals dealt with five areas and established several control agencies: (Nanto, 2009).

\section{Promote robust supervision and regulation of financial firms.}

A new Financial Services Oversight Council to identify emerging systemic risks and improve interagency cooperation; New authority for the Federal Reserve to supervise all firms that could pose a threat to financial stability; Stronger capital and other prudential standards for all financial firms, and higher standards for large, interconnected firms; A new National Bank Supervisor; The registration of advisers of hedge funds and other private pools of capital with the U.S. Securities and Exchange Commission.

\section{Built comprehensive supervision of financial markets.}

Regulation of securitization markets and all over-the-counter derivatives, including new requirements for market transparency, stronger regulation of credit rating agencies, and a requirement that issuers and originators retain a financial interest in securitized loans;

3. Protect consumers and investors from financial abuse.

A new Consumer Financial Protection Agency; Stronger regulations to improve the transparency, fairness, and appropriateness of consumer and investor products and services;

4. Provide the government with the tools it needs to manage financial crises.

A new regime to resolve nonbank financial institutions whose failure could have serious systemic effects; Revisions to the Federal Reserve's emergency lending authority to increase accountability.

\section{Raise international regulatory standards and improve international cooperation.}

Treasury proposed international reforms, including strengthening the capital framework; improving oversight of global financial markets; coordinating supervision of internationally active firms; and improving crisis management tools.

Through TARP, the Treasury has invested in dozens of banks, insurers among other financial institutions. On March 23, 2009, \$900 billion Public Private Partnership Investment Program signed by the U.S. Treasury in order to address toxic assets bared by the financial system.

Fed also conducted about $\$ 1.2$ trillion in emergency commitments to stabilize the financial sector. It was in terms of safety net for commercial banks, the rescue of Bear Stearns, a lending facility for investment banks and intermediates, loans for money-market assets and commercial paper, and purchases of securitized loans and asset-backed securities (Nanto, 2009).

Estimated ARRA tax, entitlement, and contract, grant, and loan expenditures have been increased from $\$ 787$ billion to $\$ 840$ billion. $\$ 731.9$ billion has been paid out already. 
According to Recovery Act, government has already paid out $\$ 290.7$ billion in Tax Benefits, \$249.5 billion in Entitlement Programs, \$253.1 billion in Contract, Grant and Loan Programs, which recent list of all programs in a category:

- Individual Tax Credits ( $\$ 131.8$ billion) including - First-Time Homebuyers, Transportation Subsidy, Education benefits, Earned Income Tax Credits.

- Making Work Pay (\$104.4 billion) including - \$400 tax credit for working individuals; \$800 for working married couples.

- Tax Incentives for Businesses (\$32.6 billion) including - The Work Opportunity Tax Credit added unemployed veterans and 16-to-24 year olds to the list of new hires that businesses could claim.

- Energy Incentives (\$10.9 billion) including - Tax credits for energy efficient improvements to residences. Tax credits for alternative energy equipment, Electric Vehicles Tax Credit.

- Manufacturing \& Economic Recovery, Infrastructure Refinancing, Other (\$7.3 billion) including - Tax-exempt bonds to expand industrial development. Bonds for investment in Infrastructure, job training, and education in high unemployment areas. Increased available New Market credits.

- COBRA (\$3.7 billion) including - Assistance with Continuation of Health Coverage.

- Education (\$92.3 billion) including - State Fiscal Stabilization Fund. Student Aid. Training and Employment Services. Special Education and Rehabilitative Services.

- Transportation (\$37.6 billion) Highway Infrastructure. High-Speed Rail Corridors. Grants for Railroads and Airports.

- Infrastructure (\$32 billion) including - Broadband. Federal Building Fund. Highway Construction. Rural Water and Waste Disposal Account.

- Energy / Environment (\$29.2 billion) including - Energy Efficient and Renewable Energy Program. Defense Environmental Clean-up. Electricity Delivery and Energy Reliability Program. Water and Related Resources Superfund Program.

- Housing (\$13.9 billion) including - Public and Indian Housing. Rental Assistance Programs. Homelessness Prevention Programs. Homeowners Assistance Fund.

- $\quad \boldsymbol{R} \& \boldsymbol{D}$ / Science (\$15 billion) including - Fossil Energy R\&D. National Science Foundation. National Institutes of Health.

- Health (\$9.8 billion) including - Centers for Disease Control \& Prevention. Indian Health Service. Food \& Nutrition Service. National Institutes of Health.

- Family (\$4.9 billion) including - Health Resources and Services. Veterans Health Administration. Centers for Disease Control and Prevention. Food and Nutrition Services. Supplemental Nutrition Program for Women, Infants, and Children.

- Job Training/Unemployment (\$4.7 billion) including - Community Service Employment for Older Americans. Training and Employment Services. Special Education and Rehabilitative Services. Trade Adjustment Assistance for Farmers.

- Public Safety (\$5.4 billion) including - Wild land Fire Management. FEMA Firefighter Assistance Grants and Emergency Food and Shelter. Violence Against Women Programs. Customs and Border Protection.

- Medicaid/Medicare (\$100.9 billion) including - Medicaid Grants to States; Medicare HITECH Incentive Payments; Program Management.

- Unemployment Insurance Programs (\$61.1 billion).

- Family Services (\$47.1 billion) including - Foster Care and Adoption Assistance; Child Support; Food Stamp Program; Assistance for Needy Families.

- Economic Recovery Payments (\$13.8 billion) including - One-time \$250 payments to Social Security beneficiaries; Railroad Board payments; Veterans payments. 
- Energy (\$19.9 billion) including - Grants for Specified Energy Property in Lieu of Tax Credits; Bonneville Power Administration Fund; Western Area Power Administration, Borrowing Authority.

- Housing (\$5.6 billion) including - Grants to States for Low-Income Housing in Lieu of LowIncome Tax Credits.

- Agriculture (\$0.95 billion) including - Assistance for Farm and Aquaculture Revenue Losses Due to Natural Disasters. Trade Adjustment Assistance for Farmers.

- Other Programs (\$5.9 billion) including - Some administrative and Operation Costs for Recovery Programs. Offices of the Inspectors General Recovery Administration Costs.

Trillion dollars rescue packages are launched around the world, which will generate inflation and public debt, but will help to prevent others- food and economic crises. Many countries have cut taxes to strengthen household income, promote investment and increase aggregate demand. Businesses were given an incentive to expand and create new jobs.

In addition, financial support has been channeled to specific industries, mostly the automobile industry in the United States, according to Auto Industry Finance and Restructuring Act of 2008, passed by the U.S. House of Representatives on December 10, 2008. It was controversial that failure in this industry would have had a systematic adverse effect on the economy and therefore immediate facilities to restore liquidity and stability were required. The aid aimed to preserve 355,000 jobs in the industry and up to 4.5 million in related industries.

The Stimulus package can solve the problems not just in a short run and some results are expected over decades: (Hassett, 2009)

- The stimulus bill expanded several tax credits for low-income families. It increased the earned income tax credit for working families with three or more children from 40 percent to 45 percent, the maximum credit amount from $\$ 5,028$ to $\$ 5,657$, and the income phase-out level for married couples. The total cost of the expansion is estimated at $\$ 4.7$ billion; it will cost $\$ 32.9$ billion over ten years.

- The stimulus bill also expanded the home ownership credit to include additional incentives for first-time home buyers. It increased the maximum credit to $\$ 8,000$ for married couples and allowed the credit to be delivered as a cash grant instead of an interest-free loan. The total cost of the credit is estimated to be $\$ 6.6$ billion over ten years.

- Extension to 2009 of enhanced expenses for small business, which allows businesses to instantly expense the first $\$ 25,000$ of investment in equipment; it will cost $\$ 40$ million. In addition, the stimulus extends bonus depreciation, which allows businesses to write off half the value of their qualifying investment in the year of equipment purchase. This policy, which was relied on during the previous downturn as well, has an estimated cost of $\$ 5.1$ billion.

- To encourage consumer spending in the legislation is a large deduction for automobile purchases. Vehicle buyers would be deducted all state, local, and excise taxes paid on new vehicles up to a price of $\$ 49,500$. The deduction would phase out over an income range of $\$ 125,000$ to $\$ 135,000$ for singles and $\$ 250,000$ to $\$ 260,000$ for married couples filing jointly. The provision is expected to cost $\$ 1.7$ billion over ten years.

- The new tax legislation indexes the 2008 thresholds for inflation, making the new threshold $\$ 46,700$ for singles and $\$ 70,950$ for married couples, which is estimated at $\$ 69.8$ billion.

- Tax incentives to deferral of certain income from the discharge of indebtedness ( $\$ 1.6$ billion over ten years), tax-preferred "Recovery Zone Bonds"' targeted to depressed areas (\$5.4 
billion over ten years), and the New Markets Tax Credit, a nonrefundable tax credit to investors who buy stock in companies investing in low-income areas ( $\$ 815$ million over ten years). The stimulus also generates $\$ 20$ billion in new tax incentives for alternative energy sources.

- Two top tax rates are increased from 33 and 35 percent to 36 and 39.6 percent, respectively, in 2011. The tax rate increases would generate $\$ 338.7$ billion in revenue over ten years. Increasing the tax rate of long-term capital gains and dividends from 15 to 20 percent and limiting the value of itemized deductions to 28 percent for taxpayers in the top two tax brackets, taxing carried interest as ordinary income. Those two policies would provide an increase in tax revenue of $\$ 118.1$ billion and $\$ 317.5$ billion, respectively.

- Tax changes that would directly affect businesses propose eliminating capital gains taxes on small businesses, costing $\$ 7.2$ billion over ten years. It also proposes making the research and experimentation (R\&E) tax credit permanent, which provides a 20 percent nonrefundable tax credit for all R\&E. The credit expansion will cost $\$ 74.5$ billion over ten years. The budget also proposes a "cap and trade" regime, in which corporations would buy permits allowing them to emit a predetermined level of carbon dioxide. In many respects, the regime is similar to a carbon tax. The total climate revenues raised would equal $\$ 645.7$ billion over ten years.

By January 2009, US financial institutions had written off $\$ 1$ trillion of losses. Even conventional projections expect another \$3-5 trillion of write-offs. Congress allocated $\$ 700$ billion funds for asset and equity purchases, and for merger subsidies. The Fed's balance sheet expanded to $\$ 2$ trillion as it bought assets and lent reserves to US banks and to foreign central banks. US government accumulated commitments approach $\$ 9$ trillion. Additionally securitized subprimes totaled $\$ 2.5$ trillion. Certainly the losses are not simply a matter of bad mortgages for low income borrowers to buy unaffordable suburban mansions. Rather, this is a crisis of the money manager system. Due to most of it unregulated, unreported, and off-balance sheet, there is no way to assess the ultimate scale of losses (Wray, 2009).

Financial and economic crises has left more than 26 million Americans who are out of work, cannot find full-time work, or have given up looking for work uncertain about their future prospects. About 4 million families have lost their homes to foreclosure and another 4.5 million have slipped into the foreclosure process or are seriously behind on their mortgage payments. Nearly \$11 trillion in household wealth has vanished, with retirement accounts and life savings swept away. The collateral damage has been real people and communities. The impacts of the crisis are seems to be felt for a generation (FCIC, 2011).

If these bailouts, stimulus packages were not necessary to prevent another crisis might be occurred and it would not have been necessary if the crisis was caused by actions of the government itself-then the Dodd-Frank Act (adopted by Congress in July 2010) seriously overreached (FCIC, 2011).

The crisis revealed fundamental weaknesses in financial systems not only in US, but also worldwide. While coordinated policies by governments, trillions of dollars in intervention and huge fiscal stimulus packages, the crisis seems far from completely end.

The global financial crisis has brought an important outcome: the United States is still a major center of the financial world. When the financial system in the U.S. stumbles, it may give to the rest of the world damage with it. The reason is that the United States is the main guarantor of the international financial system, the symbol of advanced capitalist economy since World War II, the provider of dollars as global currency and an international medium of exchange. 
Most scholar think to get rid of the crisis around world, firstly US has got to end this. Most economies will not recover until the US does.

\section{Conclusion}

On the one hand, US government spent lots of money to bailout financial organizations which at the same time caused the crisis. On the other hand, that was what government should do. We did expect this, because government's hand was also in that balloon. And government couldn't let it happen in that way.

Despite government's a little bit involvement in that problem, there were some attempts to curb the initial spark of turmoil with fine and penalties, FED regulations and other governmental economic, financial and social policies.

Financial institutions made, bought, and sold mortgage securities they never examined, did not care to examine, or knew to be defective; firms depended on tens of billions of dollars of borrowing that had to be renewed each and every night, secured by subprime mortgage securities; and major firms and investors blindly relied on credit rating agencies as their arbiters of risk.

Government (through FHFA, FED) found these institutions unsafe and unsound practices included the purchase and guarantee of higher-risk loan products before and on the eve of crisis. But it was either late or irrepressible. Without the bailout, defaults could have caused cascading losses and collapses in the overall financial system.

Government's prior role in this case is to avoid crisis or prevent the driving forces behind the crisis. Secondly, if there is crisis already occurred, government has to solve the problem with least cost. Let`s say, not to save all firms including key problem corporations.

Problems may appear inside the economy, but only through government interference these hardships can be resolved.

It is hard to predict, what would be government role in the next crisis, but it is clear that if that crisis would threat overall economy and social sphere, government will act instantly and in one path.

Now, capitalism learned some lessons from last financial crisis, although they couldn't treat at all. But remedies will make stronger and reliable global financial and economic system.

\section{Acknowledgements}

Both researchers are thankful to administrations of both TROY UNIVERSITY / USA and QAFQAZ UNIVERSITY / AZERBAIJAN for great facilities and kind research opportunities they provided. 


\section{REFERENCES}

1. ABI. (2010). Annual Business and Non-business Filings by Year (1980-2009). Alexandria, VA: American Bankruptcy Institute.

2. ARRA. (2009). The American Recovery and Reinvestment Act of 2009. Washington D.C.: RECOVERY ACCOUNTABILITY AND TRANSPARENCY BOARD.

3. Bernanke, B. (2010). Lessons from the Failure of Lehman Brothers. House Financial Services Committee, 111th Cong., 2nd sess. Federal Reserve.

4. Blankenburg, S., \& Palma, J. G. (2009). Introduction: the global financial crisis. Cambridge Journal of Economics, 33, p.531-538.

5. Bresser-Pereira, L. C. (2010). The global financial crisis and a new capitalism? New York: The Levy Economics Institute of Bard College, Working Paper 592.

6. Campello, M., Graham, J. R., \& Harvey, C. R. (2010). The Real Effects of Financial Constraints: Evidence from a Financial Crisis. Journal of Financial Economics 97, 470-487.

7. CBO. (2009). Addressing the Ongoing Crisis in the Housing and Financial Markets. Washington D.C.: CONGRESSIONAL BUDGET OFFICE.

8. CBO. (2010). Report on the Troubled Asset Relief Program. Washington D.C.: Congressional Budget Office.

9. CFTC. (1996). Division of Enforcement. Retrieved from http://www.cftc.gov/About/CFTCReports/index.htm

10. ESA. (2008). Economic Stimulus Act of 2008. Washington D.C.: Senate and House of Representatives of the United States of America in Congress.

11. FCIC. (2010). Preliminary Staff Report: Shadow Banking and the Financial Crisis. Washington D.C.: THE FINANCIAL CRISIS INQUIRY COMMISSION.

12. FCIC. (2011). The Financial Crisis Inquiry Report. Washington D.C.: THE FINANCIAL CRISIS INQUIRY COMMISSION.

13. Hassett, K. (2009). A Not So New Direction for Tax Policy. In T. L. Anderson, \& R. Sousa, Reacting to the Spending Spree: Policy Changes We Can Afford (pp. 35-54). Stanford, CA: HOOVER INST PRESS PUBLICATION.

14. Labonte, M. (2008). Financial Turmoil: Federal Reserve Policy Responses. Washington D.C.:Congressional Research Service, Report RL34427 research.policyarchive.org/20014.pdf

15. MMSA. (2009). The 2009 Mortgage Market Statistical Annual, vol. 1,2: The Primary Market. Rockville, MD: Inside Mortgage Finance.

16. Nanto, D. K. (2009). The Global Financial Crisis: Analysis and Policy Implications. Washington D.C.: Congressional Research Service.

17. O’Brien, T. (2004, May 28). Fed Assess Citigroup Unit $\$ 70$ Million in Loan Abuse. The New York Times.

18. OECD. (2009). Policy Responses To The Economic Crisis: Investing In Innovation For Long-Term Growth. Paris: OECD. 
19. OFHEO. (2006). Report of the Special Examination of Freddie Mac. Washington, DC: FEDERAL HOUSING FINANCE AGENCY, Special Examination Report.

20. SCF-Chartbook. (2010). Mean Value of Mortgages or Home-Equity Loans for Families with Holdings. Washington D.C.: Federal Reserve Board.

21. Taylor, J. B. (2008). The Financial Crisis and the Policy Responses: An Empirical Analysis of What Went Wrong. Cambridge: NBER Working Paper No. 14631.

22. Wilmarth Jr., A. E. (2002). The Transformation of the U.S. Financial Services Industry, 1975-2000: Competition, Consolidation and Increased Risks. University of Illinois Law Review, Vol. 2002, No. 2, 239-240.

23. Woellert, L. (2010). Treasury Fixing Home-Finance Juggles Bailout, Economy. Bloomberg, August 16.

24. Wray, L. R. (2008). Financial Markets Meltdown: What Can We Learn from Minsky. New York: Public Policy Brief No. 94. The Levy Economics Institute.

25. Wray, L. R. (2005). The Ownership Society: Social Security Is Only the Beginning. New York: The Levy Economics Institute, Public Policy Brief No. 82.

26. Wray, L. R. (2009). The Rise And Fall Of Money Manager Capitalism: A Minskian Approach. Cambridge Journal of Economics, 807-828.

27. Wray, L. R. (2011). Minsky's Money Manager Capitalism and the Global Financial Crisis. New York: The Levy Economics Institute of Bard College.

28. Zibel, A. (2012). Fed Plans to Fine Eight More Banks for Foreclosure Violations. The Wall Streeet Journal, March, p. 19. 